\title{
Dynamics of spermatial nuclei in trichogyne of the red alga Bostrychia moritziana (Florideophyceae)
}

\author{
Eunyoung Shim ${ }^{1}$, Hana Park ${ }^{1}$, Soo Hyun $\operatorname{Im}^{1}$, Giuseppe C. Zuccarello ${ }^{2}$ and Gwang Hoon \\ $\operatorname{Kim}^{1, *}$ \\ ${ }^{1}$ Department of Biological Sciences, Kongju National University, Gongju 32588, Korea \\ ${ }^{2}$ School of Biological Sciences, Victoria University of Wellington, P.O. Box 600, Wellington 6140, New Zealand
}

Red algal fertilization is unusual and offers a different model to the mechanism of intracellular transport of nuclei and polyspermy blocking. A female carpogonium (egg) undergoes plasmogamy with many spermatia (sperm) simultaneously at the receptive structure, trichogyne, which often contains numerous male nuclei. The pattern of selective transport of a male nucleus to the female nucleus, located in the cell body of the carpogonium, remain largely unknown. We tracked the movement of spermatial nuclei and cell organelles in the trichogyne after plasmogamy using time-lapse videography and fluorescent probes. The fertilization process of Bostrychia moritziana is composed of five distinctive stages: 1) gamete-gamete binding; 2) mitosis in the attached spermatia; 3) formation of a fertilization channel; 4) migration of spermatial nuclei into the trichogyne; and 5) cutting off of the trichogyne cytoplasm from the rest of the cell after karyogamy. Our results showed that actin microfilaments were involved in the above steps of fertilization, microtubules are involved only in spermatial mitosis. Time-lapse videography showed that the first ("primary") nucleus which entered to trichogyne moved quickly to the base of carpogonium and fused with the female nucleus. The transport of the primary male nucleus to the egg nucleus was complete before its second nucleus migrated into the trichogyne. Male nuclei from other spermatia stopped directional movement soon after the first one entered the carpogonial base and oscillated near where they entered trichogyne. The cytoplasm of the trichogyne was cut off at a narrow neck connecting the trichogyne and carpogonial base after gamete nuclear fusion but gamete binding and plasmogamy continued on the trichogyne. Spermatial organelles, including mitochondria, entered the trichogyne together with the nuclei but did not show any directional movement and remained close to where they entered. These results suggest that polyspermy blocking in B. moritziana is achieved by the selective and rapid transport of the first nucleus entered trichogyne and the rupture of the trichogyne after gamete karyogamy.

Key Words: Bostrychia moritziana; cytoskeleton; fertilization; polyspermy blocking; time-lapse videography

\section{INTRODUCTION}

Fertilization is one of the most important events of an organism's life cycle and consists of several well regulated steps to guarantee successful zygote formation. Polyspermy blocking, the inhibition of multiple sperm nuclei fusing with the egg nucleus, is essential to make viable zygotes. Fertilization of an egg nucleus by multiple sperm nuclei is usually lethal (Brawley 1987, Mio et al. 2012). Polyspermy blocking is achieved through various
(9) $\$$ This is an Open Access article distributed under the terms of the Creative Commons Attribution Non-Commercial License (http://creativecommons.org/licenses/by-nc/3.0/) which permits unrestricted non-commercial use, distribution, and reproduction in any medium, provided the original work is properly cited.
Received September 30, 2020, Accepted December 7, 2020

* Corresponding Author

E-mail: ghkim@kongju.ac.kr

Tel: +82-41-850-8504, Fax: +82-41-850-8479 
mechanisms. Two types of mechanisms for polyspermy blocking have been reported in mammals: the "oocyte membrane block" to sperm penetration and the "zona reaction." The former response involves a depolarization of the egg membrane caused by the influx of $\mathrm{Na}^{+}$, which changes the potential of the egg membrane from negative to positive inhibiting sperm fusion. The latter response occurs in the 'zona pellucida' in animals, once the first sperm has attached to egg membrane, changing its properties and blocking any further sperm penetration (Coy and Avilés 2009). Polyspermy blocking in sea urchins and sea worms depends on a change in the electrical charge across the surface of the egg, which is caused by the fusion of the first sperm with the egg (Jaffe 1976, GouldSomero et al. 1979). Unfertilized sea urchin eggs have a negative charge inside, but the charge becomes positive upon fertilization. When the first sperm contacts the egg and causes the electrical change, subsequent sperms are prevented from fusing. The mechanisms of nuclear fusion and maternal inheritance of cell organelles are not fully answered yet.

Plants also have evolved a battery of mechanisms that potentially act as polyspermy barriers (e.g., Tekleyohans et al. 2017, Tekleyohans and Groß-Hardt 2019). In most sexually reproducing plants, pollen grows a pollen tube which delivers one pair of sperm nuclei that ultimately fertilize two female nuclei, the egg and the two nuclei of the central cell (Russell 1993, Johnson et al. 2019). Sperm cell release and gamete fusion trigger sequential disintegration of both synergids such that typically only a single pollen tube is attracted to one ovule (Völz et al. 2013, Maruyama et al. 2015). Apart from the regulation of pollen tube growth, the plant egg is subjected to further modifications after fertilization. In rice and maize, a shielding material accumulates on the cell wall of egg and prevents supernumerary sperm cell fusion in 10-20 min after the first sperm fuses with egg (Kranz et al. 1995, Toda et al. 2016).

In fucoid brown algae, polyspermy is lethal with zygote development ceasing at the four-cell stage (Brawley 1987). To circumvent the fatal consequences of supernumerary gamete fusion, fucoid algae have evolved a sodium-dependent polyspermy block similar to the "oocyte membrane block" in animals (Brawley 1987, 1991). Secretion of cell wall material upon exposure of calcium ionophores has been reported in these algae suggesting that calcium mediates vesicle release into the egg extracellular matrix thereby establishing a permanent block to polyspermy (Brawley and Bell 1987, Brawley 1990, 1991). In green algae, the proteins involved in gamete recogni- tion and fusion has been reported as an intermediate means of polyspermy block (e.g., Bianchi and Wright 2014). FUS1 and HAP2 proteins are two gamete-specific components essential for gamete fusion in Chlamydomonas (Ferris et al. 1996, Misamore et al. 2003, Liu et al. 2008). These proteins become eliminated from the plasma membrane after gamete fusion, which results in the reduction in the fusion capacity of the gametes and prevents polygamy (Liu et al. 2010).

Fertilization in red algae is unusual, partially due to their lack of any flagellated stages (Picket-Heaps and West 1998). The receptive area of the egg (carpogonium), the trichogyne, is an elongated extension of the carpogonium and relatively long-lived, and it is covered by cell wall material, which is possibly an adaptation to passive receiving of sperm (Kim and Fritz 1993a, 1993b). The sperm (spermatia), also surround by wall material and appendages, is passively transported to the trichogyne. The surface of the trichogyne, in many red algae, can accommodate a large number of attached spermatia (Picket-Heaps and West 1998).

There is no apparent change in cell membrane potential after gamete binding in red algae. Numerous spermatia simultaneously bind to trichogyne and develop fertilization channels, which leads to multiple plasmogamy, therefore there is also no apparent changes in extracellular matrix to block additional binding (Kim and Fritz 1993a, Mine and Tatewaki 1994, Picket-Heaps and West 1998). Each spermatium that attaches to the trichogyne undergo mitosis and discharges two nuclei together with other cell organelles into trichogyne. It has been suggested that an actin-myosin machinery is involved in the migration of spermatial nuclei into and along the trichogyne (Kim and Kim 1999a, Wilson et al. 2002). Previous study using time-lapse videography in the red alga Bostrychia moritziana showed that two spermatial nuclei move in different directions within trichogyne, one going to the base of carpogonium, potentially fusing with the egg nucleus, and the other migrates to the opposite direction, towards a tip of the trichogyne. It has been suggested that the two nuclei in each spermatium are differentiated so that only one is capable of fertilization, differentiation being visibly expressed in their directional movement (Picket-Heaps and West 1998). This scenario would indicate that when multiple plasmogamy occur several spermatial nuclei could move to the carpogonium cell body, and potentially fuse with the egg nucleus, producing polyspermic fertilization.

In this study we examined the fertilization process of B. moritziana to answer the following questions: What 
mechanism is involved in spermatial nuclear movement and what is the fate of nuclei that do not fuse with the carpogonial nucleus? We used time-lapse videography combined with image analysis system and fluorescent probes to trace the dynamics of spermatial organelles inside the carpogonium.

\section{MATERIALS AND METHODS}

\section{Algal cultures}

Gametophytes (male and female) of B. moritziana were obtained from the John A. West culture collection (culture number \#2746) and samples deposited in National Marine Biodiversity Institute of Korea (MABIK) (KNU culture No. KNU000027, KNU000028) were used. The thalli were maintained in unialgal cultures in IMR medium (Kim et al. 2005) at $20^{\circ} \mathrm{C}$ in a $16: 8 \mathrm{~h}$ light : dark cycle with illumination of $>20 \mu \mathrm{mol}$ photons $\mathrm{m}^{-2} \mathrm{~s}^{-1}$ provided by cool-white fluorescent lighting. The plants were transferred every 1-2 weeks to new IMR medium. For fertilization experiments, subcultures of 5 to 10 shoot tips approximately $1 \mathrm{~cm}$ long were transferred to fresh medium in $100 \mathrm{~mL}$ dishes a week before use. These plants were checked for growth and reproduction daily. Male and female gametophytes actively developing spermatangial stichidia and carpogonial branches with visible trichogynes, respectively, were used.

\section{Preparations for microscopy}

To induce spermatial release individual male shoot tips with well-developed spermatangial stichidia were exposed to osmotic shock by placing into distilled water for $30 \mathrm{~s}$ (Picket-Heaps and West 1998). The male was then removed from the suspension of spermatia and several female shoot tips with visible trichogynes were added and the dish was gently agitated to promote mixing and contact of spermatia with the trichogynes. The female branches were then quickly placed in seawater on a well-cleaned glass slide and a coverslip added. Excess water was blotted from the edge and the whole mount was sealed with Valap $(1: 1: 1: 1$ mixture of paraffin wax, lanolin and Vaseline, melted at about $40^{\circ} \mathrm{C}$ (Picket-Heaps and West 1998). Within 2-5 min of spermatial contact the slide was placed on the video microscopy system.

\section{Microscopy, fluorescent probes and image analysis}

Samples prepared as above were examined on an Olympus BX51 research microscope (Tokyo, Japan) equipped with differential interference contrast (DIC) optics and Samsung iPolis camera (Samsung, Suwon, Korea), with an oil-immersion condenser. Single frame photographs were taken every $3 \mathrm{~s}$ for $120 \mathrm{~min}$ and all the frames were amalgamated into video clips using a timelapse program (VideoVelocity, CandyLabs, Vancouver, Canada).

To visualize actin microfilaments, female with trichogynes and attached spermatia were fixed for $30 \mathrm{~min}$ in $3.7 \%(\mathrm{w} / \mathrm{v})$ formaldehyde diluted in microfilamentstabilizing buffer (MFSB) consisting of $10 \mathrm{mM}$ EGTA, 5 $\mathrm{mM} \mathrm{MgSO}_{4}$, and $100 \mathrm{mM}$ PIPES-KOH (pH 6.9) (Traas et al. 1987). The trichogynes were rinsed three times with MFSB, and then placed for $30 \mathrm{~min}$ in $0.5 \%$ (v/v) Triton $\mathrm{X}-100$ diluted in MFSB. The algae were washed three times with MFSB before being placed in a solution of BODIPY FITC-phallacidin (Invitrogen, Carlsbad, CA, USA) (Wieland et al. 1983) for 3-6 $\mathrm{h}$ at $4^{\circ} \mathrm{C}$ in the dark. FITC-phallacidin was prepared as a stock solution of 300 units $\mathrm{mL}^{-1}$ in methanol and was stored at $-20^{\circ} \mathrm{C}$ in the dark. The stock was diluted with MFSB to a final concentration of 1.5 units $\mathrm{mL}^{-1}$. For dual staining of nucleus, Hoeschst33342 stain was diluted in IMR medium as $1 \mu \mathrm{L}$ $\mathrm{mL}^{-1}$ and cells were stained in $1.5 \mathrm{~mL}$ tube for $15 \mathrm{~min}$ in the dark before observation under microscope.

For microtubule labelling, female trichogynes with attached spermatia were fixed in 3.7\% formaldehyde diluted with phosphate-buffered saline (PBS; $8 \mathrm{mM}$ $\mathrm{Na}_{2} \mathrm{HPO}_{4}, 2 \mathrm{mM} \mathrm{NaH} \mathrm{PO}_{4}, 140 \mathrm{mM} \mathrm{NaCl}$; $\mathrm{pH}$ 7.4) for 30 min and then rinsed three times in the same buffer. The trichogyne were cut off from the female plant with a razor blade to allow antibody entry into the cytoplasm, and incubated overnight in the dark with the monoclonal anti-alpha-tubulin antibody conjugated to fluorescein isothiocyanate (Sigma-Aldrich, St. Louis, MO, USA), diluted at a $1: 40$ ratio in PBS. For dual staining of nucleus, Hoeschst33342 was added to the solution $\left(1 \mu \mathrm{mL}^{-1}\right)$ for 15 min before observation.

For the general stain for vacuolar inclusions in spermatia and trichogynes DRAQ5 (Thermo Fisher, Seoul, Korea) solution diluted as $1 \mu \mathrm{L} 1 \mathrm{~mL}^{-1}$ in IMR medium and applied to the sample after gamete mixing. DRAQ5 is originally developed as a cell permeable far-red fluorescent DNA dye that can be used in fixed or live cells. We found this drug stains all vacuolar structures of B. morit- 

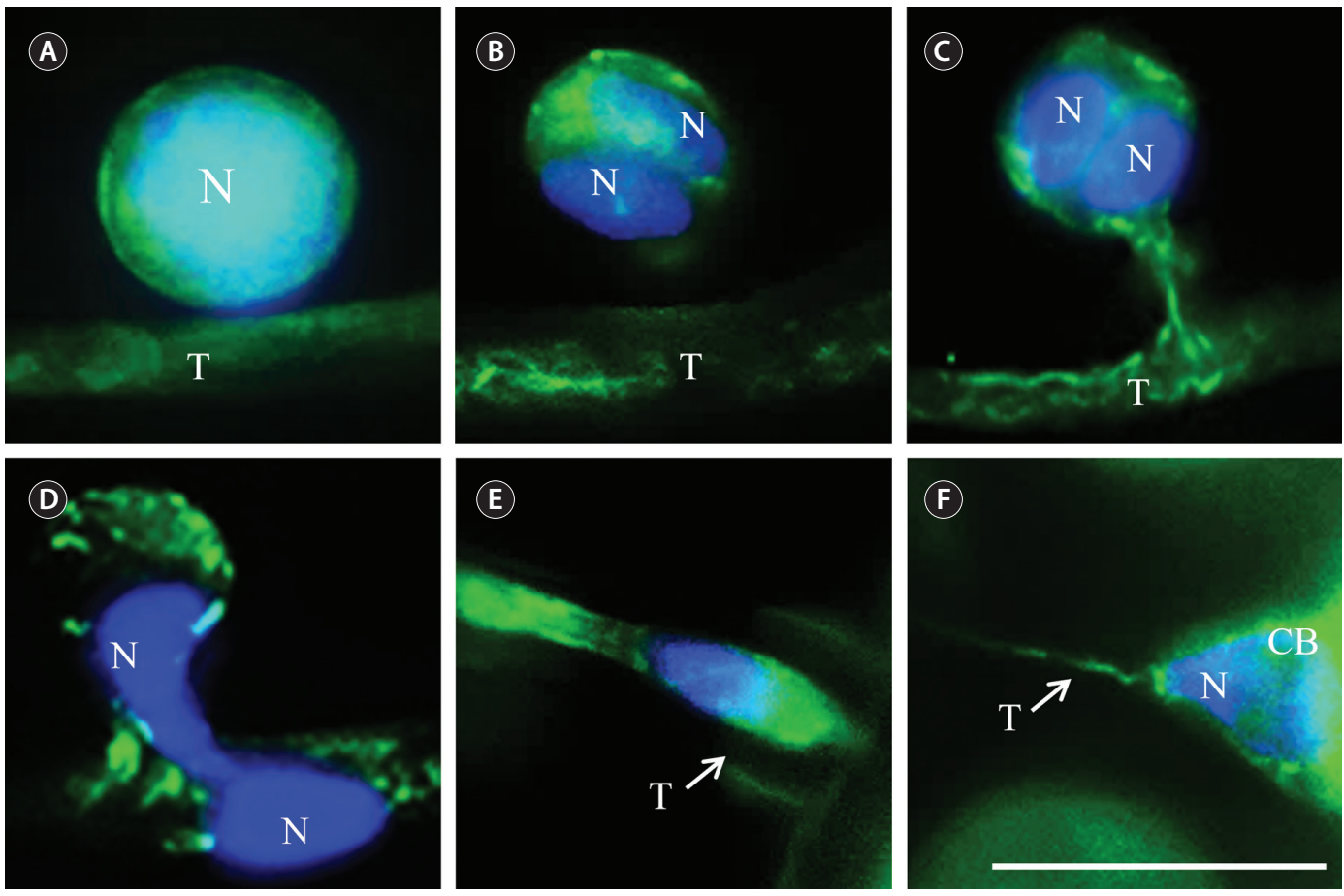

Fig. 1. Microfilaments during fertilization in Bostrychia moritziana. (A) Microfilaments distribute evenly on the periphery of spermatium at time of attachment. (B) Spermatium enter mitosis soon after attachment. Microfilaments separate two daughter nuclei. (C) Fertilization channel developed and microfilaments of spermatium and trichogyne connected through it. (D) Spermatial nucleus migrates into trichogyne. (E) Spermatial nucleus enclosed by microfilaments moving towards the base of the carpogonium. (F) Spermatial nucleus migrated into the base of the carpogonium. Microfilaments connecting trichogyne and carpogonial base became thinner and disconnected. Spermatial nuclei stained blue with Hoeschst33342 and microfilaments stained green with FITC-phallacidin. N, spermatial nucleus; T, trichogyne; CB, carpogonial base. Scale bar represents: $10 \mu \mathrm{m}$.

ziana cells in blue under a light microscope. We used it as a counter stain to observe nuclear movement in trichogyne using DIC optics.

Chromeo a live cell mitochondrial staining kit (Santa Cruz Biotechnology, Santa Cruz, CA, USA) was stored in a $100 \mathrm{mM}$ stock solution in solubilizing buffer at $-20^{\circ} \mathrm{C}$. To observe mitochondria, the stock solution was diluted to $1 \mu \mathrm{L} 1 \mathrm{~mL}^{-1}$ in IMR medium and cells were stained for $30 \mathrm{~min}$ prior to observation on a fluorescent microscope.

An image analysis program (Image-pro plus 7.0; Media Cybernetics, Warrendale, PA, USA) was used to measure the direction and velocity of male nuclei and organelles movement in the trichogyne. To measure distance of male organelle movement, the video clips taken from each experimental set up were analyzed using a motion tracking system as follows: A spot was marked on the nuclei or male organelles appearing in the frame of the time-lapse clip, and distance traveled by each spot in 1 min was shown as a peak in the graph. Each line in the graph represents the distance that each spot traveled. Each peak that one spot made was traced as a line graph over time. When the nucleus moved more quickly, the spots marked on nuclei traveled a greater distance in a given time. The final distance of each nucleus from the fertilization channel to the base of carpogonium was measured and presented as a bar graph.

\section{RESULTS}

\section{The cytoskeleton during the fertilization process}

Early in gamete binding, microfilaments in spermatia were distributed evenly on the periphery of the spermatium, surrounding the central nucleus, and microfilaments in the trichogyne are also fairly evenly distributed in the cytoplasm (Fig. 1A). When spermatia became closely appressed to the trichogyne, they enter mitosis within $20 \mathrm{~min}$. At this time, microfilaments accumulated at the center plate separating the two daughter nuclei (Fig. 1B). A fertilization channel, between spermatia and trichogyne, began to develop around 30-40 min af- 

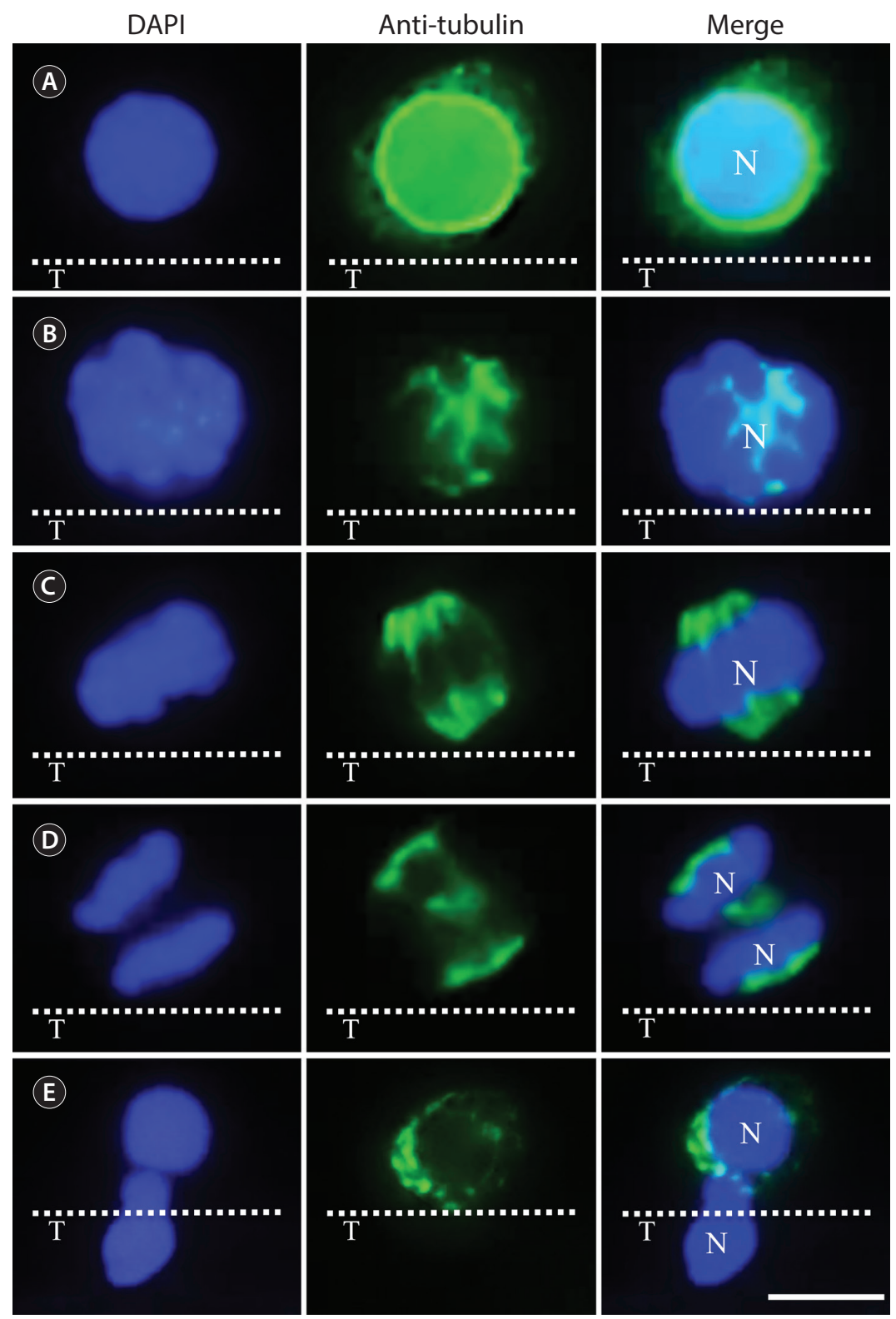

Fig. 2. Microtubules during the early stages of fertilization. (A) Even distribution of microtubules around periphery of the spermatium during the initial stage of gamete binding. (B) Microtubules now found in center of the cell close to metaphase plate. (C) At metaphase, microtubules located at each polar region of dividing nucleus forming the spindle. (D) At telophase, microtubule accumulated at the center plate between the two daughter nuclei. (E) During the migration of spermatial nuclei into the trichogyne microtubules in spermatium degenerated. Some microtubules remained in the peripheral region of the spermatium. Spermatial nuclei stained blue with Hoeschst33342 and microtubules stained green with FITC-conjugated alpha-tubulin antibody. Micrographs of Hoeschst33342 staining (DNA), tubulin and merged image. The surface of trichogyne was marked with dashed line. N, spermatial nucleus; T, trichogyne. Scale bar represents: $5 \mu \mathrm{m}$.

ter gamete binding and microfilament bridged between the two cells through this fertilization channel (Fig. 1C). When spermatial nuclei migrate into the trichogyne some spermatial microfilaments remain in the spermatia body (Fig. 1D). Spermatial nuclei became elongated and surrounded with microfilaments while moving in the trichogyne (Fig. 1E). After a spermatial nucleus migrated into the base of carpogonium, the microfilaments in the region connecting the trichogyne and carpogonial base became thin and fragmentary (Fig. 1F).

Microtubules were observed only in spermatia (Fig. 2). Extensive amount of tubulin (microtubules) was ob- 

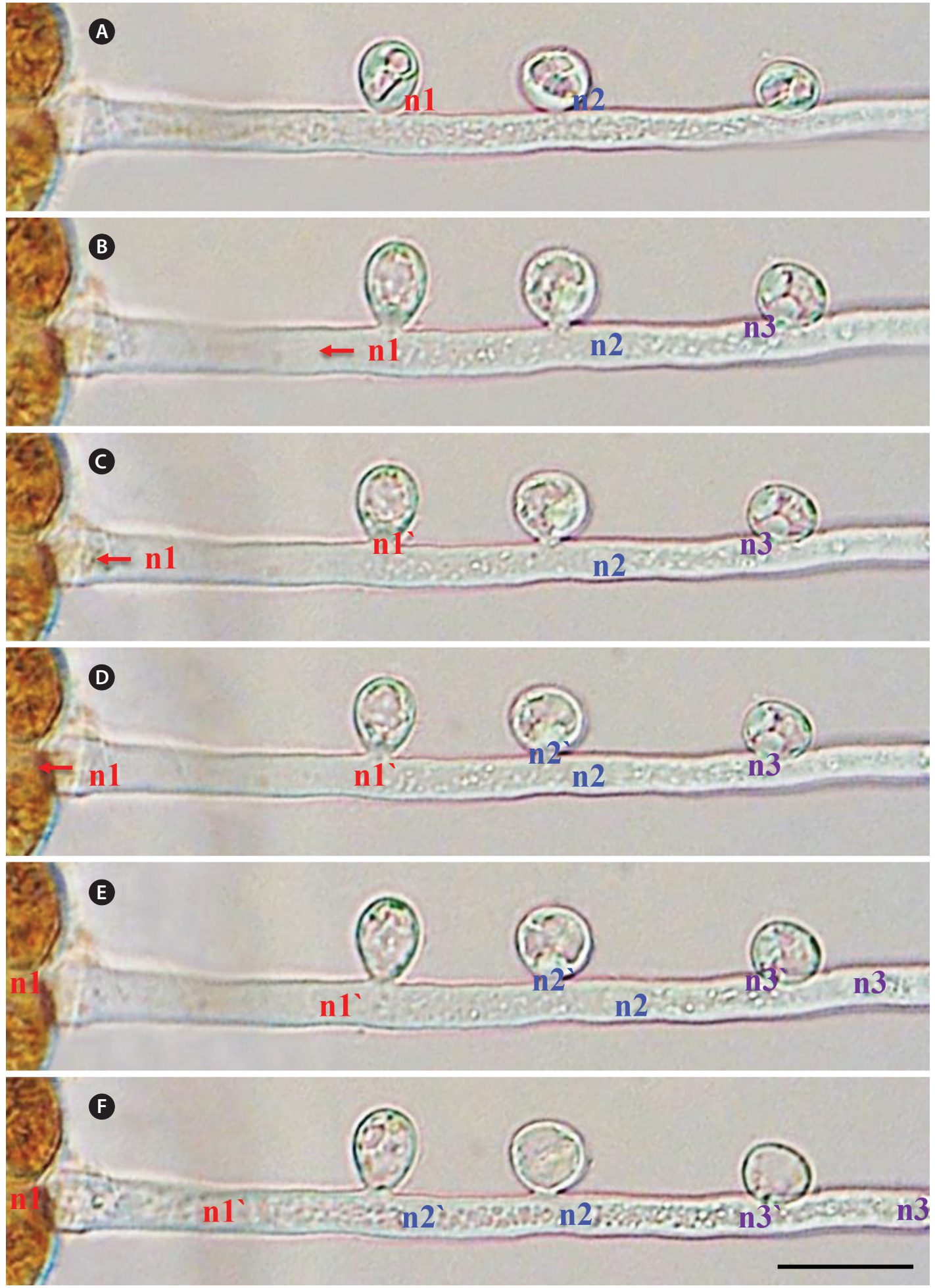

Fig. 3. Time-lapse videograph of multiple plasmogamies and the migration of spermatial nuclei in a trichogyne. (A) Mitosis occurred in attached spermatia and multiple plasmogamy occurred nearly simultaneously along the surface of trichogyne. (B) The first nucleus ( $\mathrm{n} 1$ ) to enter trichogyne followed by the first nucleus from the other spermatium (n2) also entered. (C) The first nucleus (n1) moved towards the base of carpogonium, but the second nucleus ( $\mathrm{n} 2$ ) did not move in that direction but oscillated near the fusion area. (D) The first nucleus ( $\mathrm{n} 1$ ) reached to the base of carpogonium and the second nucleus ( $\mathrm{n}^{\prime}$ ) from the same spermatium entered the trichogyne. The nucleus from the third spermatium (n3) entered the trichogyne. (E) The first nucleus (n1) entered the carpogonial base and all other spermatial nuclei remained around where they entered. (F) The other spermatial nuclei (n1', n2, n2', n3, n3`) showed slow oscillation in the trichogyne. Scale bar represents: $10 \mu \mathrm{m}$. 

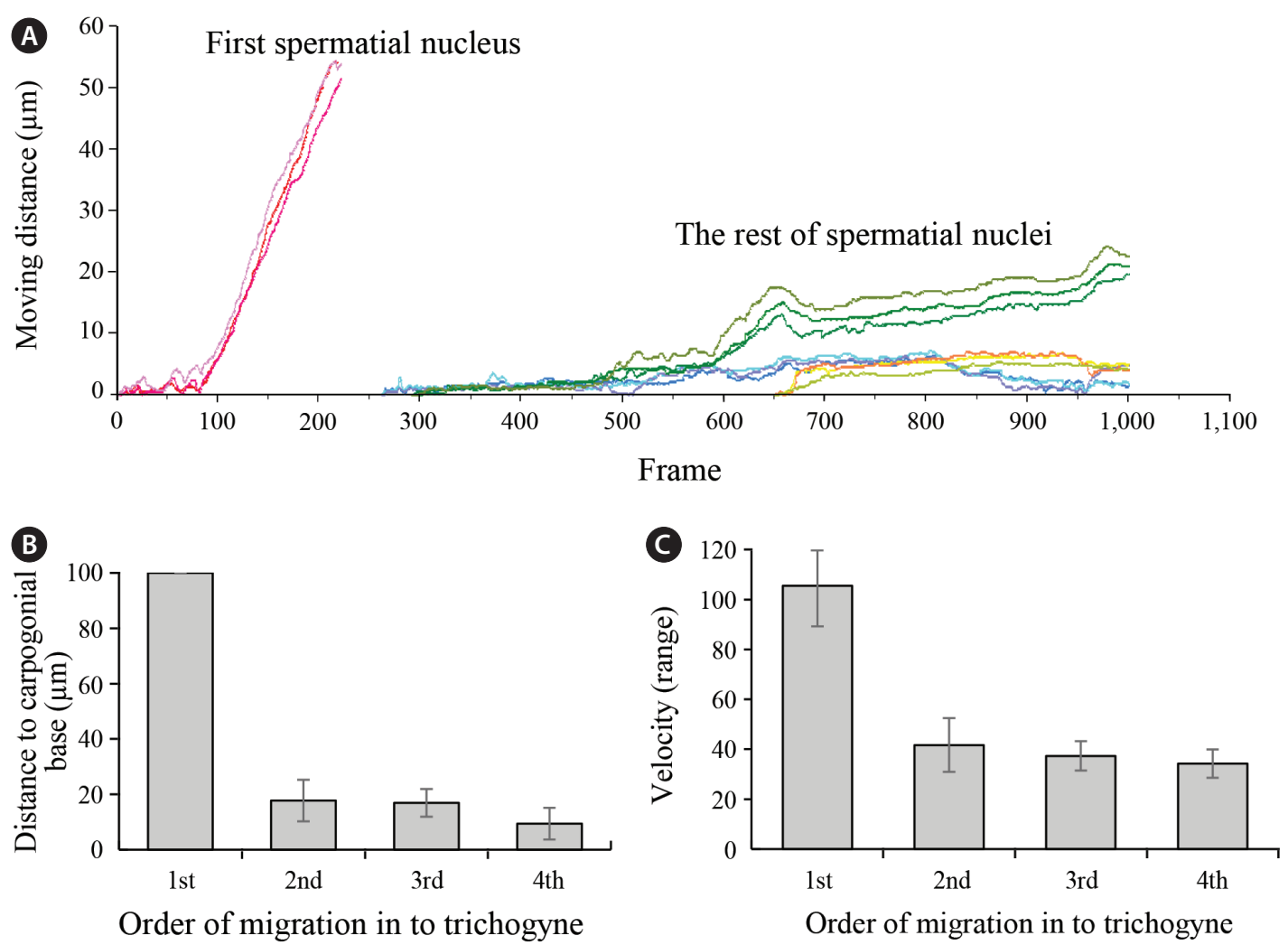

Fig. 4. Image analysis of time-lapse footages on spermatial movement in trichogyne. (A) Moving distance by time, measured as number of frames, of each male nucleus inside trichogyne. Note the first male nucleus move much faster and further than the other nuclei. (B) Comparison of moving distance of spermatial nuclei in order of the entrance to trichogyne. The first male nucleus moves much longer distance than the others. (C) Velocity of the spermatial nuclei in order of the entrance to trichogyne.

served on the surface of spermatia at the initial stage of gamete binding (Fig. 2A). During prometaphase microtubules disappeared from the surface and moved to the center close to the metaphase plate (Fig. 2B). At metaphase microtubules moved to polar region of dividing nuclei (Fig. 2C). Microtubule began to appear at the center plate between the two daughter nuclei during telophase (Fig. 2D). There was no cytokinesis, so the spermatium remained binucleate. When spermatial nuclei migrated into the trichogyne, microtubules began to disappear and remnant microtubules remained in the spermatium (Fig. 2E). Microtubules were not observed in the trichogyne surface nor on the fertilization channel during the fertilization processes (Fig. 2E).

\section{Movement of spermatial nuclei and organelles within the trichogyne}

Multiple plasmogamy occurred almost simultaneously between a trichogyne and spermatia (Fig. 3). Often numerous spermatia, attached to a trichogyne, started mitosis simultaneously and all developed fertilization channels (Fig. 3A). The first nucleus to enter the trichogyne from the 'primary' spermatium began to move towards the base of carpogonium soon after it entered the trichogyne (Fig. 3B). Often the first nucleus from the other spermatium (n2) entered the trichogyne before the second nucleus (n1') of the primary spermatium entered the trichogyne (Fig. 3B). The second nucleus (n1') eventually followed the first nucleus towards the base of carpogonium but did not pass the narrow neck that connects the trichogyne with the carpogonial base (Supplementary Video S1). Although several nuclei entered the trichogyne over a short interval only the first one (primary nucleus) to enter migrated all the way to the base of carpogonium (Fig. 3C-E). The other nuclei in the trichogyne did not show any particular directional movement but showed slow oscillations, after the primary nucleus had entered the carpogonial base (Fig. 3F). Often the cytoplasm at the base of the trichogyne cut off at the nar- 

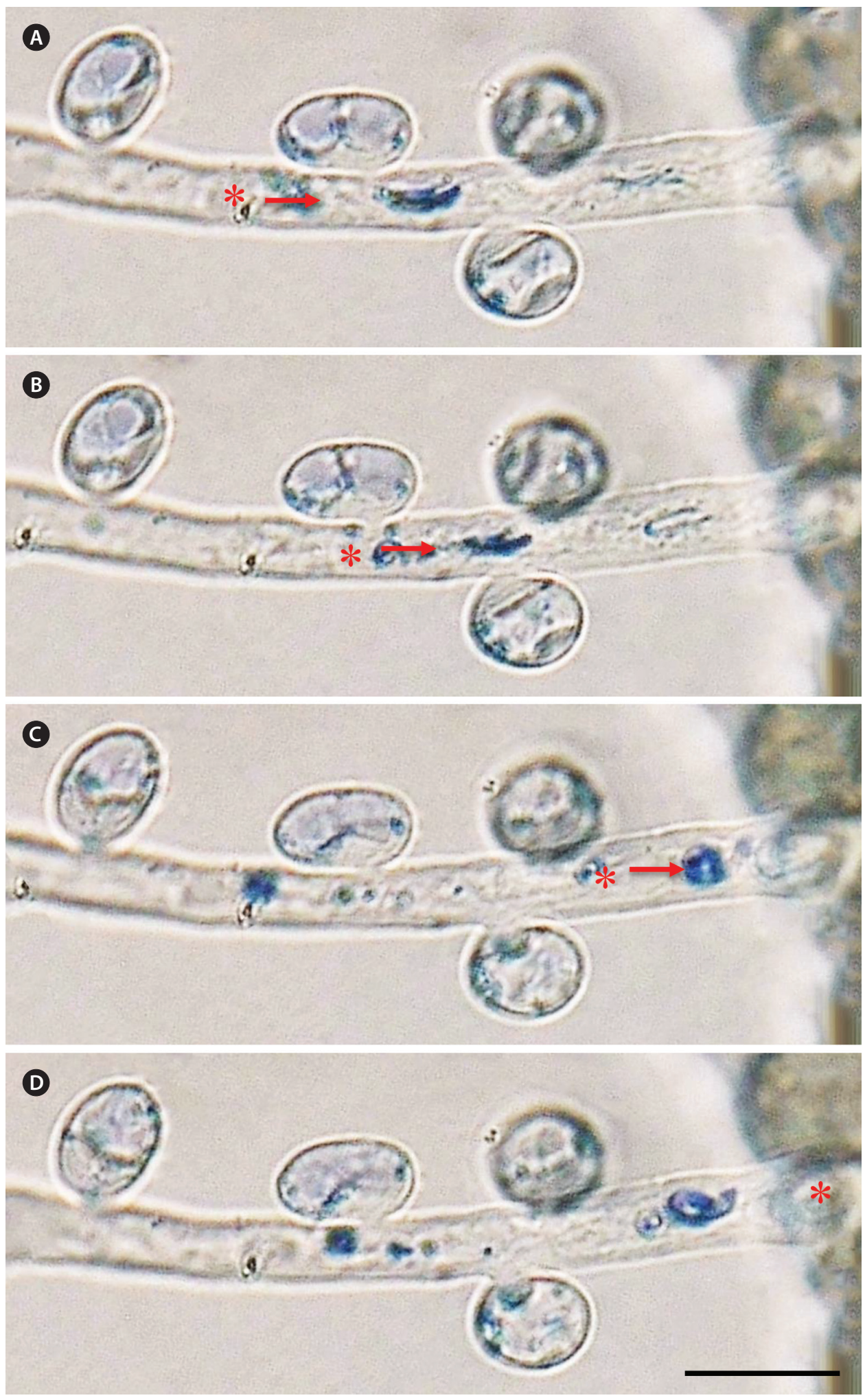

Fig. 5. Movement of male nucleus in trichogyne with DRAQ5 staining. Membranous organelles in spermatium and trichogyne were stained blue. (A) The male nucleus (*) was in contact with blue-stained organelles in trichogyne. (B) Some stained membranous organelles in the trichogyne were pushed towards the carpogonial base together with the male nucleus. (C) Primary spermatial nucleus proceed around the organelles. (D) Primary spermatial nucleus $\left(^{*}\right)$ entered the base of carpogonium and female organelles moved back close to original position. Scale bar represents: $10 \mu \mathrm{m}$. 

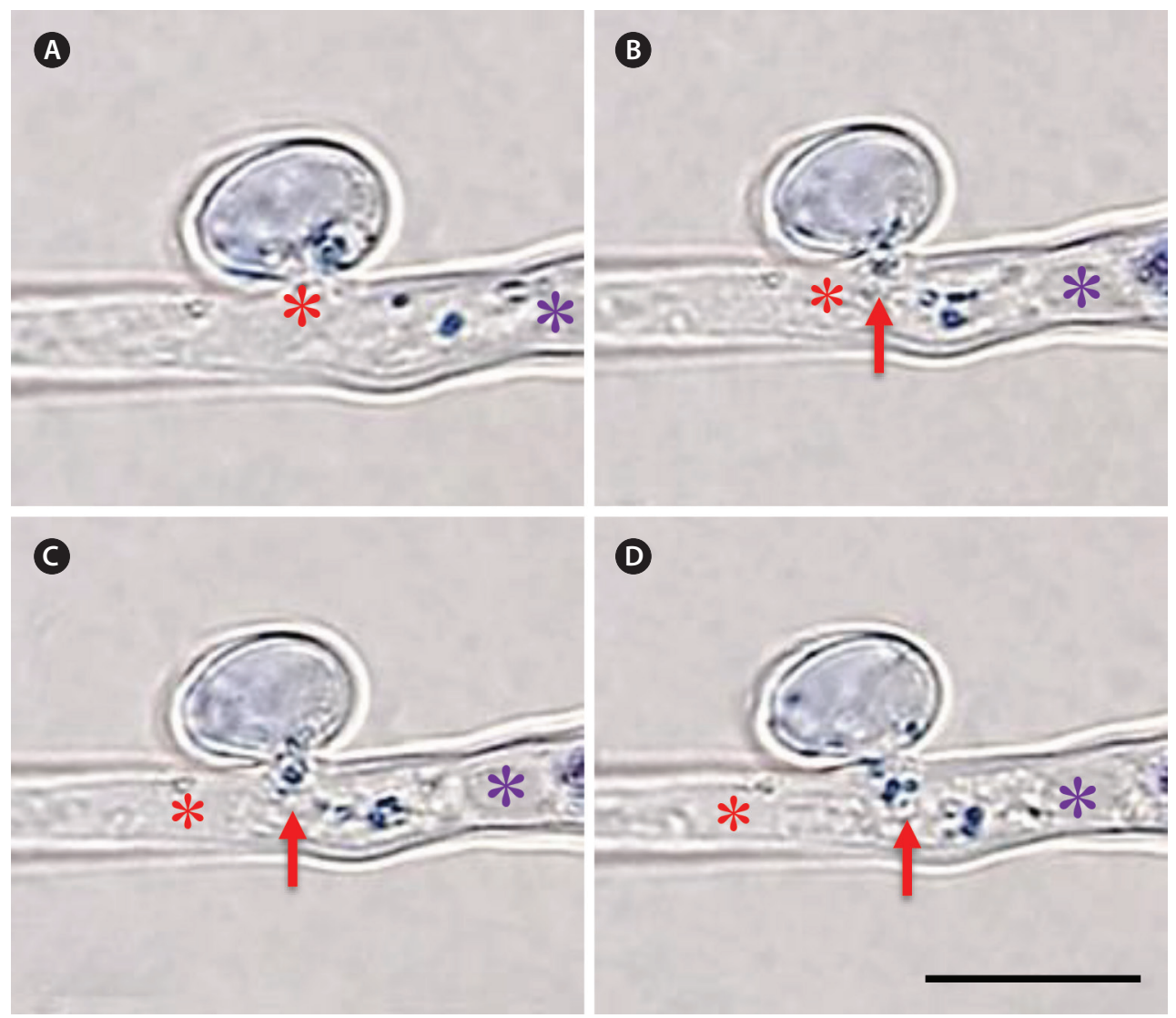

Fig. 6. Movement of spermatial membranous organelles during plasmogamy. (A) When male nucleus entered the trichogyne some organelles entered also. (B) Spermatial organelles trapped between two spermatial nuclei. (C) Spermatial organelles remain where they were discharged when the first spermatial nucleus entered the carpogonial base. (D) At late stage of fertilization, spermatial organelles still staying where they were discharged. ${ }^{*}$, the spermatial nuclei; red arrow, the spermatial organelles. Scale bar represents: $5 \mu \mathrm{m}$.

row neck connecting the trichogyne to the carpogonial cell body after the first spermatial nucleus passed that point. Image analysis result showed that the first spermatial nucleus moved faster and further than the other nuclei inside the trichogyne (Fig. 4A \& B).

The cytoplasm of trichogyne was filled with numerous membranous organelle-like inclusions which oscillated all the time. These organelles were not distinctive in the light microscope unless stained with DRAQ5 and became blue. When the first spermatial nucleus proceed to these obstacles the organelles were pushed towards the base of carpogonium (Fig. 5A \& B). The spermatial nucleus left them behind when it passed the narrow neck connecting the trichogyne to the carpogonial base (Fig. 5C \& D, Supplementary Video S2). In spermatia, these blue staining bodies mostly degenerated during the development of the fertilization channel, but some survived until plasmogamy and entered to trichogyne together with the nu- clei (Fig. 6). Often, some male organelles were discharged before the first nucleus migrated into the trichogyne (Fig. $6 \mathrm{~A} \& \mathrm{~B})$, but as this first nucleus proceed towards the carpogonial base, it left these organelles behind (Fig. 6C \& D, Supplementary Video S3). The shape of mitochondria in the spermatia was distinctive and each mitochondria was discrete at the initial stage of fertilization (Fig. 7A), but they became smaller and often aggregated into irregular shaped masses at later stages, e.g., mitosis in spermatia (Fig. 7B \& C). Some spermatial mitochondria followed the migrating male nucleus into the trichogyne after plasmogamy, but remained close to the fertilization channel (Fig. 7D).

Inclusions in the trichogyne cytoplasm changed after the first spermatil nucleus passed the narrow neck of carpogonium (Fig. 8, Supplementary Video S4). The cytoplasm initially was filled with many small vesicle-like structures which oscillated all the time (Fig. 8A-C). These 

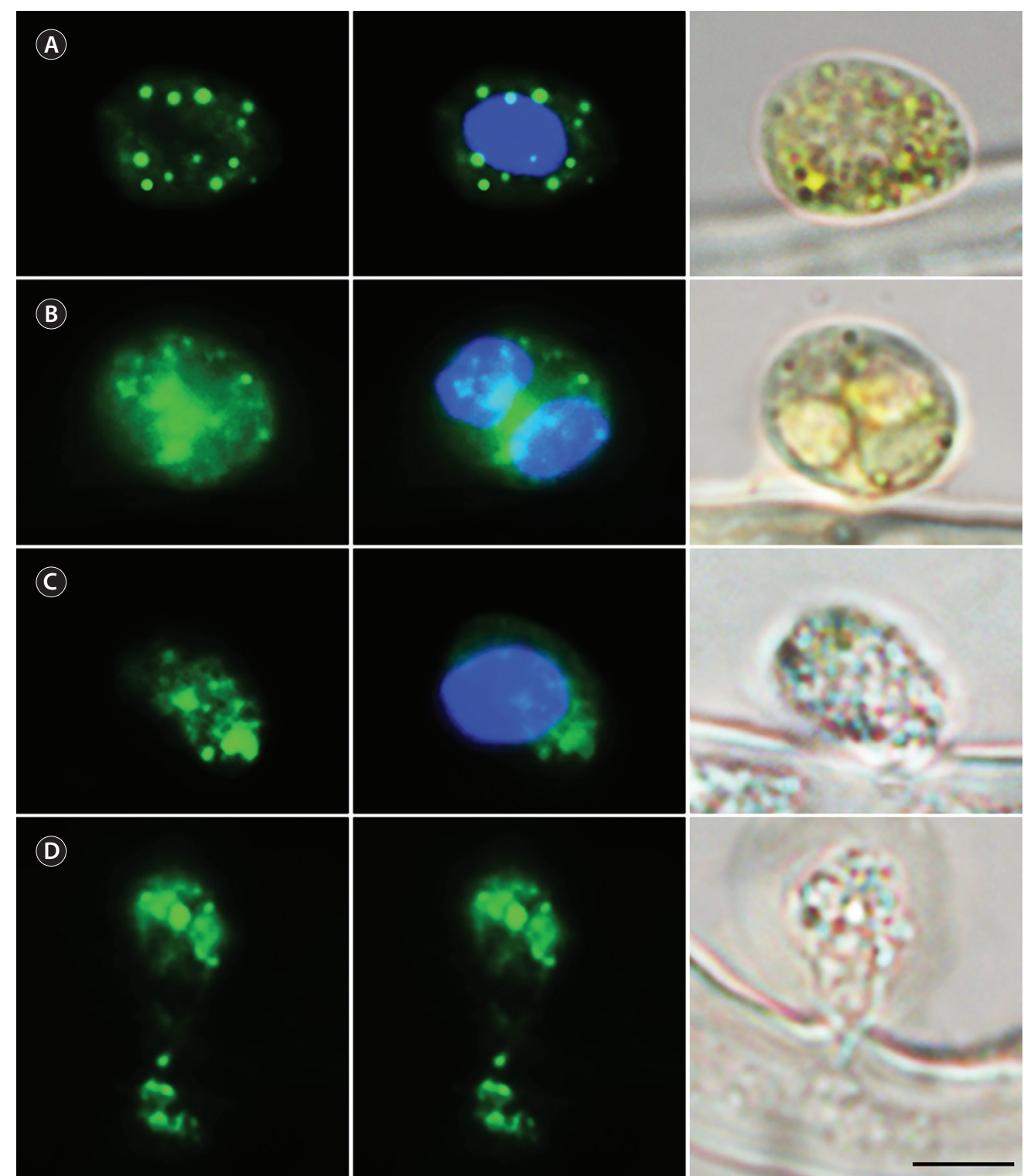

Fig. 7. Spermatial mitochondria stained with fluorescent probe Chromeo. (A) At the initial stages of gamete binding mitochondria in spermatium are distinctive and separate from each other. (B) When spermatium enters mitosis, the number of mitochondria decreases and some of them agglutinate to form irregular masses. (C) Most mitochondria degenerated or fused during mitosis. (D) Some mitochondria entered the trichogyne through the fertilization channel. Spermatial nuclei stained blue with Hoeschst33342 and mitochondria stained green with Chromeo, light image also shown. Scale bar represents: $5 \mu \mathrm{m}$.

structures disappeared at later stages of fertilization and many large vacuoles appeared in the cytoplasm (Fig. 8D $\&$ E). The other male nuclei were trapped between these vacuoles (Fig. 8F, Supplementary Video S4). When plasmogamy occurred simultaneously, the first nucleus from the secondary spermatium followed the first primary nucleus to the base of the carpogonium but did not enter the cell body (Supplementary Video S5) as the cytoplasm of the trichogyne was cut off at the narrow neck and there was a total collapse of the trichogyne cytoplasm after the first nucleus entered (Supplementary Video S5). Spermatial binding, as well as nuclear division, still occurred when newly released spermatia were added to the trichogyne even after the cytoplasm had collapsed, but all spermatia aborted without the development of a fertilization channel (Supplementary Video S6). 

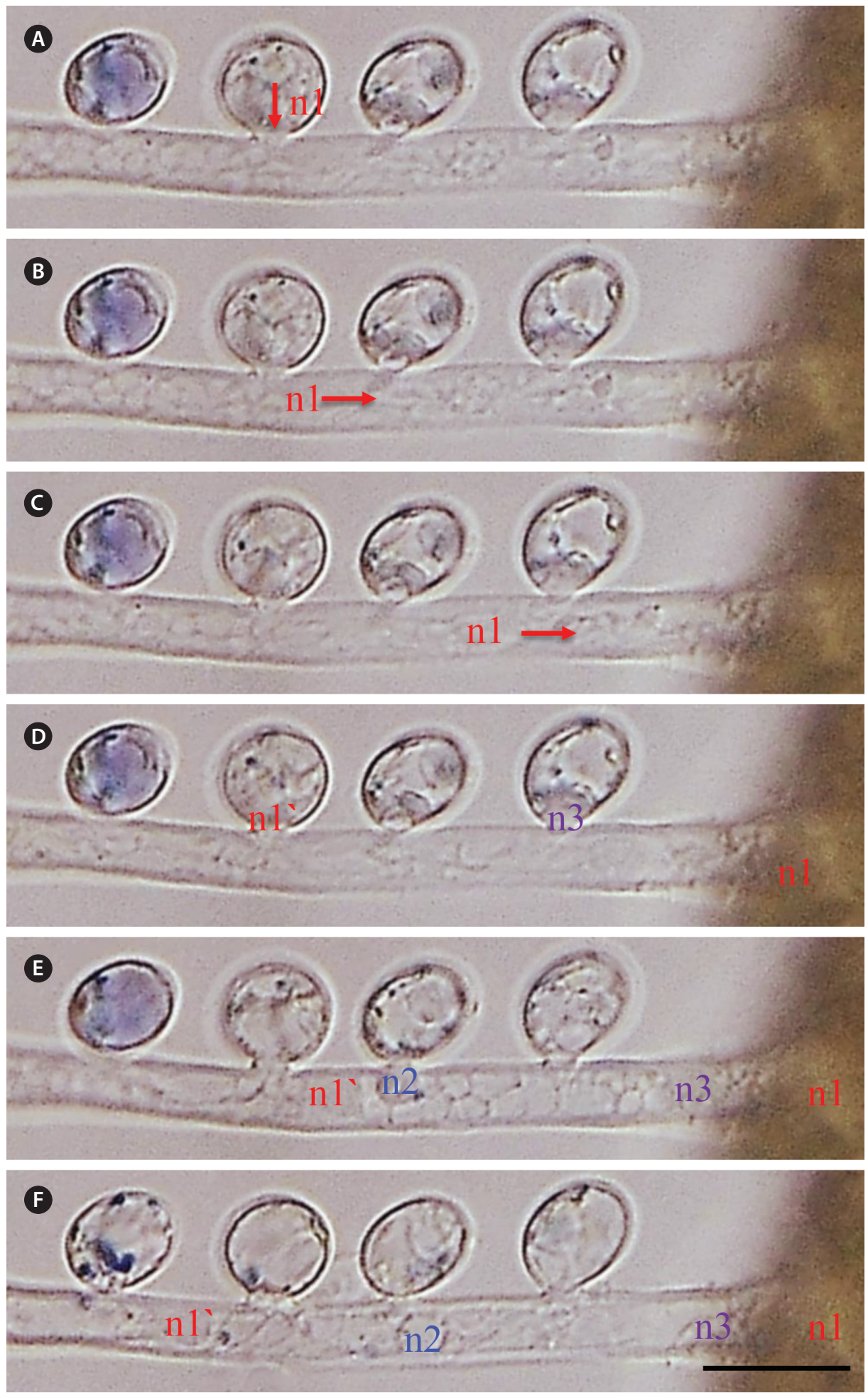

Fig. 8. The changes in the cytoplasm of trichogyne during fertilization. (A) Trichogyne cytoplasm was filled with small vesicle-like structures showing oscillating movements. (B) Primary spermatial nucleus moved into the trichogyne ( $\mathrm{n} 1$ ) not blocked by these vesicles. (C) Movement of male nucleus ( $\mathrm{n} 1$ ) continues toward the base of trichogyne. (D) Many vesicles disappeared after the primary male nucleus enters the carpogonial base. (E) Most vesicles disappeared in the trichogyne cytoplasm and the space began to be filled with large vacuoles. (F) Before the collapse of the trichogyne, the whole trichogyne cytoplasm was filled with swollen vacuoles. $\mathrm{n} 1$, the first male nucleus entered trichogyne; $\mathrm{n} 1$;, the second nucleus of the primary spermatium; n2, the first nucleus of the secondary spermatium; n3, the first nucleus of the tertiary spermatium. Scale bar represents: $10 \mu \mathrm{m}$. 


\section{DISCUSSION}

The fertilization process was followed in close detail in B. moritziana and showed features that have not been reported before. Our results showed that both spermatial nuclei could move towards the same direction but only the first (primary) nucleus to enter the trichogyne was transported rapidly and directionally to the base of carpogonium while the other nuclei including nuclei from other spermatia stopped directional movement when the first one entered the carpogonial base. This is contrary to previous reports which suggest that two nuclei in each spermatium are differentiated to move to opposite directions so that only one is capable of fertilization (PickettHeaps and West 1998).

Our observation of multiple plasmogamy in trichogynes, some even occurring after putative karyogamy, suggests that polyspermy blocking works by another mechanism in red algae different from other organisms. There was no apparent change in the cell membrane potential of a carpogonium after the gamete binding and plasmogamy in B. moritziana. In many organisms, including brown algae, polyspermy blocking is achieved by an electric depolarization of the oocyte membrane within seconds after gamete fusion (e.g., Brawley 1991). It could be suggested that the non-motility of gametes of red algae may have led to the loss of this electrical polarity block to polyspermy. Although red algal spermatia have long appendages to increase effective reach and enhance gamete binding (Kugrens 1980, Fetter and Neushul 1981, Magruder 1984, Pueschel 1990, Broadwater et al. 1991, Kim and Fritz 1993a, 1993b), it may not be efficient enough compared to flagella-based directional movements which specifically bring both gametes together. As fertilization channels between spermatia and trichogyne are easy to collapse during the development the presence of some back-up spermatia undergoing plasmogamy may be helpful to ensure successful fertilization. PicketHeaps and West (1998) suggested that a collapse of the trichogyne after fertilization may be an active means of preventing polyspermy in B. moritziana. Our results partially support this, we observed that there was a block, possibly involving microfilament disruption, at the neck between the trichogyne and carpogonial cell body, after the primary nucleus entered the base. It is also possible that the increase in vacuoles, and blocking of movement within the trichogyne cytoplasm, after fertilization are a secondary means of reducing the chance of polyspermy.

Multiple binding of spermatia may be needed for the success of fertilization. Fertilization involving multiple plasmogamy has been reported in some animals (Hemmings and Birkhead 2015). Bird eggs are penetrated by multiple sperms without any polyspermy blocking, and polyspermy is somehow crucial to the development of the bird embryo. Although multiple plasmogamy occurs in the cell membrane egg nucleus fuses with only one sperm nucleus to form a viable zygote. When the egg of chicken was inseminated with low dose of sperm and few sperm penetrated the egg, the bird embryo was unlikely to survive, but the embryo survived better when the egg was penetrated with multiple sperms (Hemmings and Birkhead 2015). It has been suggested that extra sperm may somehow support cell cycles necessary for early embryo development. It is an interesting topic for future study to determine if the number of spermatia attached to one trichogyne has something to do with the success of fertilization or development of zygotes.

Nuclear division in the spermatium following its attachment to the trichogyne is regarded as a common feature of sexual reproduction in Ceramiales red algae (e.g., Kim and Kim 1999a, Wilson et al. 2002). Why do red algal spermatia enter mitosis before plasmogamy while only one nucleus is needed to fuse with the female nucleus? Picket-Heaps and West (1998) suggested that two spermatial nuclei may be differentiated after the mitosis because both nuclei from each spermatium enter the trichogyne but only one was transported to the base of carpogonium and fertilizes the carpogonial nucleus. They reported that differentiation of the two nuclei was usually immediately apparent from the direction in which they move, which in all cases was in opposite directions along the cytoplasm of the trichogyne. Whatever transport systems operate within the trichogyne, sibling nuclei appeared to engage them independently so that their destination and fates are different (Picket-Heaps and West 1998). Our results showed that it is not probable and not even necessary that two spermatial nuclei from a spermatium are differentiated. If each spermatium discharges one nucleus which can be engaged with female transport system, we should observe several male nuclei move together to the carpogonial base when multiple plasmogamy occurred in short intervals. We observed that only the first nucleus that entered the trichogyne showed rapid directional movement to the base of the carpogonium. It was the only nucleus to proceed around the vacuole-like organelles which fill the space in trichogyne cytoplasm. The second nucleus as well as some nuclei from the other spermatia also initially showed directional movements toward the carpogonial base but were trapped between these obstacles and stopped moving 
when the first one entered the carpogonial base. This is contrary to previous reports which suggest that two nuclei in each spermatium move to opposite directions; one goes to carpogonial base and the other up to the tip of trichogyne (Pickett-Heaps and West 1998).

A distinctive change in microfilaments was observed in different stages of fertilization. Microfilaments bridge between the cytoplasm of the two fused gametes, enclosed male nucleus while it is transported in trichogyne and degenerated at the neck of carpogonium after putative karyogamy. A transportation system based on actinmyosin has been proposed for bringing a male nucleus to a female nucleus (Kim and Kim 1999a, Wilson et al. 2002). To infer myosin activity in these studies, indirect evidence using non-specific myosin inhibitors were used. However, genome studies showed that there is no myosin homologue in any reported red algal genomes, which limits interpretation of cytoplasmic dynamics in red algae as microfilament-mediated phenomena (e.g., Brawley et al. 2017). Accumulating genomic evidences showed that red algae lack the complexity and diversity of cytoskeletal elements present in other multicellular lineages (Matsuzaki et al. 2004, Bhattacharya et al. 2013, Collén et al. 2013, Nakamura et al. 2013, Schönknecht et al. 2013, Brawley et al. 2017). It is probable that a novel cytoskeletal protein fills the role of myosin during fertilization because there is a transportation system working in bringing a male nucleus to carpogonial nucleus in anyways.

Microtubules within spermatia in the early stage of red algal fertilization were observed for the first time. Microtubules were not observed anywhere else in gamete fusion. There are few ultrastructural studies on visualizing the cytoskeleton of red algae during fertilization as conventional fixation methods cannot preserve structures including trichogyne adequately (Picket-Heaps and West 1998). Broadwater and Scott (1982), using electron microscopy, described parallel microtubules along the long axis of trichogyne, this is the only report of microtubules in the trichogyne so far. Microtubule inhibition experiments disrupted spermatial mitosis (Wilson et al. 2002) but not nuclear transport inside trichogynes (Kim and Kim 1999a, Wilson et al. 2002). Our results also showed an extensive network of microtubules in spermatia during mitosis. However, we did not observe any microtubules in the trichogyne or the fertilization channels between gametes. Further studies on the cytoskeletonin red algal fertilization will reveal very noble genes and cytoskeletal motor proteins involved in intracellular movement.

Red algae have evolved a fertilization system that takes advantage of existing water movement as they have nonmotile gametes. Spermatia only bind to female trichogynes through a specific lectin-carbohydrate complementary system (Kim and Fritz 1993b, Kim et al. 1995, Kim and Kim, 1999b, Han et al. 2012, Shim et al. 2012). To compensate the inefficiency of fertilization resulted from non-motility of gametes, red algae have a complicated life cycle involving parasitic carposporophyte on female gametophyte (Searles 1980). Multiple plasmogamy occurring in the early stage of fertilization may be necessary to prepare more back-up spermatia in case collapse of fertilization channel before the carpogonial nucleus get fertilized. If there is no highly selective transport system, it will cause serious problem in the formation of viable zygote.

Polyspermy is not the only issue. Our results also suggest the mechanism of organelle inheritance in red algae. In molecular studies investigating the inheritance of organelles in B. moritziana, it appears that organelle (plastids and mitochondria) inheritance is maternal (Zuccarello et al. 1999a, 1999b). Our observations of the movement of spermatial mitochondria suggests that they do not move far from the fertilization channel, explaining their maternal inheritance, as they never reach the developing zygote. Following the fate of plastids in this fertilization system would be worthwhile also pursuing.

We cannot tell whether the events we describe above are common to sexual reproduction in other red algae. Neither do we know what cytoskeletal motor elements are involved in this rapid directional movement. Further studies combining genome data with cytological observation may reveal the transportation machinery working in red algal fertilization.

\section{ACKNOWLEDGEMENTS}

We thank Kongju National University internal grant for the sabbatical leave of GHK. This research was supported by Marine Biotechnology Program of the Korea Institute of Marine Science and Technology Promotion (KIMST) funded by the Ministry of Oceans and Fisheries (MOF) (No. 20170431) and the National Research Foundation of Korea (NRF) grant (No. 2019M3C1B7025093) to GHK.

\section{SUPPLEMENTARY MATERIALS}

Supplementary Video S1. Mitosis, plasmogamy and movement of spermatial nuclei in trichogyne of Bostry- 
chia moritziana. $\mathrm{nl}$, the first spermatial nucleus entered trichogyne; nl', the second nucleus of the spermatium which finished plasmogamy; $\mathrm{n} 2$, the first nucleus of the spermatium which finished plasmogamy to the second (https://e-algae.org).

Supplementary Video S2. Movement of male nucleus in trichogyne. The first nucleus proceed around female organelles (https://e-algae.org).

Supplementary Video S3. Movement of male organelles in trichogyne (https://e-algae.org).

Supplementary Video S4. The changes occurring to inclusions in the trichogyne cytoplasm after the first male nucleus passed the narrow neck of carpogonium (https://e-algae.org).

Supplementary Video S5. Trichogyne cytoplasm cut off after the first male nucleus enter the carpogonial base (https://e-algae.org).

Supplementary Video S6. Spermatial binding and mitosis occurring on the trichogyne after the cytoplasm cut off (https://e-algae.org).

\section{REFERENCES}

Bhattacharya, D., Price, D. C., Chan, C. X., Qiu, H., Rose, N., Ball, S., Weber, A. P. M., Arias, M. C., Henrissat, B., Coutinho, P. M., Krishnan, A., Zäuner, S., Morath, S., Hilliou, F., Egizi, A., Perrineau, M. -M. \& Yoon, H. S. 2013. Genome of the red alga Porphyridium purpureum. Nat. Commun. 4:1941.

Bianchi, E. \& Wright, G. J. 2014. Izumo meets Juno: preventing polyspermy in fertilization. Cell Cycle 13:2019-2020.

Brawley, S. H. 1987. A sodium-dependent, fast block to polyspermy occurs in eggs of fucoid algae. Dev. Biol. 124:390-397.

Brawley, S. H. 1990. The polyspermy block in fucoid algae. In Wiessner, W., Robinson, D. G. \& Starr, R. C. (Eds.) Cell Walls and Surfaces, Reproduction, Photosynthesis. Experimental Phycology, Vol. 1. Springer-Verlag, Berlin, pp. 134-144.

Brawley, S. H. 1991. The fast block against polyspermy in fucoid algae is an electrical block. Dev. Biol. 144:94-106.

Brawley, S. H. \& Bell, E. 1987. Partial activation of Fucus eggs with calcium ionophores and low-sodium seawater. Dev. Biol. 122:217-226.

Brawley, S. H., Blouin, N. A., Ficko-Blean, E., Wheeler, G. L., Lohr, M., Goodson, H. V., Jenkins, J. W., Blaby-Haas, C. E., Helliwell, K. E., Chan, C. X., Marriage, T. N., Bhattacharya, D., Klein, A. S., Badis, Y., Brodie, J., Cao, Y., Collén, J., Dittami, S. M., Gachon, C. M. M., Green, B. R.,
Karpowicz, S. J., Kim, J. W., Kudahl, U. J., Lin, S., Michel, G., Mittag, M., Olson, B. J. S. C., Pangilinan, J. L., Peng, Y., Qiu, H., Shu, S., Singer, J. T., Smith, A. G., Sprecher, B. N., Wagner, V., Wang, W., Wang, Z. -Y., Yan, J., Yarish, C., Zäuner-Riek, S., Zhuang, Y., Zou, Y., Lindquist, E. A., Grimwood, J., Barry, K. W., Rokhsar, D. S., Schmutz, J., Stiller, J. W., Grossman, A. R. \& Prochnik, S. E. 2017. Insights into the red algae and eukaryotic evolution from the genome of Porphyra umbilicalis (Bangiophyceae, Rhodophyta). Proc. Natl. Acad. Sci. U. S. A. 114:E6361E6370.

Broadwater, S. T. \& Scott, J. 1982. Ultrastructure of early development in the female reproductive system of Polysiponia harveyi Bailey (Ceramiales, Rhodophyta). J. Phycol. 18:427-441.

Broadwater, S. T., Scott, J. L. \& West, J. A. 1991. Spermatial appendages of Spyridia filamentosa (Ceramiaceae, Rhodophyta). Phycologia 30:189-195.

Collén, J., Porcel, B., Carré, W., Ball, S. G., Chaparro, C., Tonon, T., Barbeyron, T., Michel, G., Noel, B., Valentin, K., Elias, M., Artiguenave, F., Arun, A., Aury, J. -M., Barbosa-Neto, J. F., Bothwell, J. H., Bouget, F. -Y., Brillet, L., CabelloHurtado, F., Capella-Gutiérrez, S., Charrier, B., Cladière, L., Cock, J. M., Coelho, S. M., Colleoni, C., Czjzek, M., Da Silva, C., Delage, L., Denoeud, F., Deschamps, P., Dittami, S. M., Gabaldón, T., Gachon, C. M. M., Groisillier, A., Hervé, C., Jabbari, K., Katinka, M., Kloareg, B., Kowalczyk, N., Labadie, K., Leblanc, C., Lopez, P. J., McLachlan, D. H., Meslet-Cladiere, L., Moustafa, A., Nehr, Z., Collén, P. N., Panaud, O., Partensky, F., Poulain, J., Rensing, S. A., Rousvoal, S., Samson, G., Symeonidi, A., Weissenbach, J., Zambounis, A., Wincker, P. \& Boyen, C. 2013. Genome structure and metabolic features in the red seaweed Chondrus crispus shed light on evolution of the Archaeplastida. Proc. Natl. Acad. Sci. U. S. A. 110:5247-5252.

Coy, P. \& Avilés, M. 2009. What controls polyspermy in mammals, the oviduct or the oocyte? Biol. Rev. 85:593-605.

Ferris, P. J., Woessner, J. P. \& Goodenough, U. W. 1996. A sex recognition glycoprotein is encoded by the plus matingtype gene fus1 of Chlamydomonas reinhardtii. Mol. Biol. Cell 7:1235-1248.

Fetter, R. \& Neushul, M. 1981. Studies on developing and released spermatia in the red alga, Tiffaniella snyderae (Rhodophyta). J. Phycol. 17:141-159.

Gould-Somero, M., Jaffe, L. A. \& Holland, L. Z. 1979. Electrically mediated fast polyspermy block in eggs of the marine worm, Urechis caupo. J. Cell Biol. 82:426-440.

Han, J. W., Klochkova, T. A., Shim, J. B., Yoon, K. \& Kim, G. H. 2012. Isolation and characterization of a sex-specific lectin in a marine red alga, Aglaothamnion oosumiense 
Itono. Appl. Environ. Microbiol. 78:7283-7289.

Hemmings, N. \& Birkhead, T. R. 2015. Polyspermy in birds: sperm numbers and embryo survival. Proc. R. Soc. B 282:20151682.

Jaffe, L. A. 1976. Fast block to polyspermy in sea urchin eggs is electrically mediated. Nature 261:68-71.

Johnson, M. A., Harper, J. F. \& Palanivelu, R. 2019. A fruitful journey: pollen tube navigation from germination to fertilization. Annu. Rev. Plant Biol. 70:809-837.

Kim, G. H. \& Fritz, L. 1993a. Gamete recognition during fertilization in a red alga Antithamnion nipponicum. Protoplasma 174:69-73.

Kim, G. H. \& Fritz, L. 1993b. Ultrastructure and cytochemistry of early spermatangial development in Antithamnion nipponicum (Ceramiaceae, Rhodophyta). J. Phycol. 29:797-805.

Kim, G. H. \& Kim, S. -H. 1999a. The role of F-actin during fertilization in the red alga Aglaothamnion oosumiense (Rhodophyta). J. Phycol. 35:806-814.

Kim, G. H., Klochkova, T. A., Yoon, K. -S., Song, Y. -S. \& Lee, K. P. 2005. Purification and characterization of a lectin, bryohealin, involved in the protoplast formation of a marine green alga Bryopsis plumosa (Chlorophyta). J. Phycol. 42:86-95.

Kim, G. H., Lee, I. K. \& Fritz, L. 1995. The wound-healing responses of Antithamnion nipponicum and Griffithsia pacifica (Ceramiales, Rhodophyta) monitored by lectins. Phycol. Res. 43:161-166.

Kim, S. -H. \& Kim, G. H. 1999b. Cell-cell recognition during the fertilization in a red alga Aglaothamnion oosumiense (Ceramiaceae, Rhodophyta). Hydrobiologia 398/399:8189.

Kranz, E., von Wiegen, P. \& Lörz, H. 1995. Early cytological events after induction of cell division in egg cells and zygote development following in vitro fertilization with angiosperms gametes. Plant J. 8:9-23.

Kugrens, P. 1980. Electron microscopic observations on the differentiation and release of spermatia in the marine red alga Polysiphonia hendryi (Ceramiales, Rhodomelaceae). Am. J. Bot. 67:519-528.

Liu, Y., Misamore, M. J. \& Snell, W. J. 2010. Membrane fusion triggers rapid degradation of two gamete-specific, fusion-essential proteins in al membrane block to polygamy in Chlamydomonas. Development 137:1473-1481.

Liu, Y., Tewari, R., Ning, J., Blagborough, A. M., Garbom, S., Pei, J., Grishin, N. V., Steele, R. E., Sinde, R. E., Snell, W. J. \& Billker, O. 2008. The conserved plant sterility gene HAP2 functions after attachment of fusogenic membranes in Chlamydomonas and Plasmodium gametes. Genes Dev. 22:1051-1068.
Magruder, W. H. 1984. Reproduction and life history of the red alga Galaxaura oblongata (Nemaliales, Galaxauraceae). J. Phycol. 20:402-409.

Maruyama, D., Völz, R., Takeuchi, H., Mori, T., Igawa, T., Kurihara, D., Kawashima, T., Ueda, M., Ito, M., Umeda, M., Nishikawa, S. -I., Groß-Hardt, R. \& Higashiyama, T. 2015. Rapid elimination of the persistent synergid through a cell fusion mechanism. Cell 161:907-918.

Matsuzaki, M., Misumi, O., Shin-I, T., Maruyama, S., Takahara, M., Miyagishima, S. -Y., Mori, T., Nishida, K., Yagisawa, F., Nishida, K., Yoshida, Y., Nishimura, Y., Nakao, S., Kobayashi, T., Momoyama, Y., Higashiyama, T., Minoda, A., Sano, M., Nomoto, H., Oishi, K., Hayashi, H., Ohta, F., Nishizaka, S., Haga, S., Miura, S., Morishita, T., Kabeya, Y., Terasawa, K., Suzuki, Y., Ishii, Y., Asakawa, S., Takano, H., Ohta, N., Kuroiwa, H., Tanaka, K., Shimizu, N., Sugano, S., Sato, N., Nozaki, H., Ogasawara, N., Kohara, Y. \& Kuroiwa, T. 2004. Genome sequence of the ultrasmall unicellular red alga Cyanidioschyzon merolae 10D. Nature 428:653-657.

Mine, I. \& Tatewaki, M. 1994. Gamete surface and attachment during fertilization of Palmaria sp. (Palmariales, Rhodophyta). Jpn. J. Phycol. 42:291-299.

Mio, Y., Iwata, K., Yumoto, K., Kai, Y., Sargant, H. C., Mizoguchi, C., Ueda, M., Tsuchie, Y., Imajo, A., Iba, Y. \& Nishikori, K. 2012. Possible mechanism of polyspermy block in human oocytes observed by time-lapse cinematography. J. Assist. Reprod. Genet. 29:951-956.

Misamore, M. J., Gupta, S. \& Snell, W. J. 2003. The Chlamydomonas Fus1 protein is present on the mating type plus fusion organelle and required for a critical membrane adhesion event during fusion with minus gametes. Mol. Biol. Cell 14:2530-2542.

Nakamura, Y., Sasaki, N., Kobayashi, M., Ojima, N., Yasuike, M., Shigenobu, Y., Satomi, M., Fukuma, Y., Shiwaku, K., Tsujimoto, A., Kobayashi, T., Nakayama, I., Ito, F., Nakajima, K., Sano, M., Wada, T., Kuhara, S., Inouye, K., Gojobori, T. \& Ikeo, K. 2013. The first symbiont-free genome sequence of marine red alga, Susabi-nori (Pyropia yezoensis). PLoS ONE 8:e57122.

Pickett-Heaps, J. \& West, J. 1998. Time-lapse video observations on sexual plasmogamy in the red alga Bostrychia. Eur. J. Phycol. 33:43-56.

Pueschel, C. M. 1990. Cell structure. In Cole, K. M. \& Sheath, R. G. (Eds.) Biology of the Red Algae. Cambridge University Press, Cambridge, pp. 7-41.

Russell, S. D. 1993. The egg cell: development and role in fertilization and early embryogenesis. Plant Cell 5:13491359.

Schönknecht, G., Chen, W. -H., Ternes, C. M., Barbier, G. 
G., Shrestha, R. P., Stanke, M., Bräutigam, A., Baker, B. J., Banfield, J. F., Garavito, R. M., Carr, K., Wilkerson, C., Rensing, S. A., Gagneul, D., Dickenson, N. E., Oesterhelt, C., Lercher, M. J. \& Weber, A. P. M. 2013. Gene transfer from bacteria and archaea facilitated evolution of an extremophilic eukaryote. Science 339:1207-1210.

Searles, R. B. 1980. The strategy of the red algal life history. Am. Nat. 115:113-120.

Shim, E., Shim, J., Klochkova, T. A., Han, J. W. \& Kim, G. H. 2012. Purification of a sex-specific lectin in gamete binding of Aglaothamnion callophyllidicola (Rhodophyta). J. Phycol. 48:916-924.

Tekleyohans, D. G. \& Groß-Hardt, R. 2019. New advances and future directions in plant polyspermy. Mol. Reprod. Dev. 87:370-373.

Tekleyohans, D. G., Mao, Y., Kägi, C., Stierhof, Y. -D. \& GroßHardt, R. 2017. Polyspermy barriers: a plant perspective. Curr. Opin. Plant Biol. 35:131-137.

Toda, E., Ohnishi, Y. \& Okamoto, T. 2016. Development of polyspermic rice zygotes. Plant Physiol. 171:206-214.

Traas, J. A., Doonan, J. H., Rawlins, D. J., Shaw, P. J., Watts, J. \& Lloyd, C. W. 1987. An actin network is present in the cytoplasm throughout the cell cycle of carrot cells and associates with the dividing nucleus. J. Cell Biol. 105:387-395.

Völz, R., Heydlauff, J., Ripper, D., von Lyncker, L. \& GroßHardt, R. 2013. Ethylene signaling is required for synergid degeneration and the establishment of a pollen tube block. Dev. Cell 25:310-316.

Wieland, T., Miura, T. \& Seeliger, A. 1983. Analogs of phalloidin: D-Abu2-Lys7-phalloin, an F-actin binding analog, its rhodamine conjugate (RLP) a novel fluorescent F-actin-probe, and D-Ala2-Leu7-phalloin, an inert peptide. Int. J. Pept. Protein Res. 21:3-10.

Wilson, S. M., Pickett-heaps, J. D. \& West, J. A. 2002. Fertilization and the cytoskeleton in the red alga Bostrychia moritziana (Rhodomelaceae, Rhodophyta). Eur. J. Phycol. 37:509-522.

Zuccarello, G. C., Burger, G., West, J. A. \& King, R. J. $1999 a$. A mitochondrial marker for red algal intraspecific relationships. Mol. Ecol. 8:1443-1447.

Zuccarello, G. C., West, J. A., Kamiya, M. \& King, R. J. 1999 b. A rapid method to score plastid haplotypes in red seaweeds and its use in determining parental inheritance of plastids in the red alga Bostrychia (Ceramiales). Hydrobiologia 401:207-214. 